\title{
(Re)Claiming Voices: Digital Storytelling and Second Language Learners
}

\author{
Yurimi Grigsby - Carolyn Theard-Griggs - Christopher \\ Lilly $^{*}$
}

\begin{abstract}
With almost five million English language learners in the United States, digital storytelling is increasingly being used in second language learning classrooms. As a teaching and learning strategy, digital storytelling can promote critical thinking, connect new content with prior knowledge, enhance memory, and foster confidence and motivation for learning. Digital stories possess unique narrative qualities that often center on identity negotiation and the ways culturally and linguistically diverse students make meaning out of their lives. Fostering hands-on, active learning, digital storytelling is an interactive way to include culturally and linguistically diverse students' voices in a curriculum that may not easily represent them. Practical implementation of digital storytelling is included.

Key words: digital storytelling, technology, English language learners.
\end{abstract}

Digital storytelling (DST) has been implemented as an instructional strategy in second and foreign language classrooms (Vinogradova, 2014) because it is highly adaptable to content and promotes student engagement. Rance-Roney defined a digital story as "a 2- to 5- minute movie-like digital production that learners create using one of several readily available software programs" (Rance-Roney, 2008, p. 29). Meadows (2003) described digital stories as short, individual, multimedia stories. As a teaching and learning strategy, DST can promote critical thinking (Yang and $\mathrm{Wu}, 2012$ ), enable a connection between newly-presented content with prior knowledge through knowledge, wisdom, and value sharing (Malita and Martin, 2010), promote memory enhancement (Schank, 1990), and encourage a higher level of confidence and motivation for learning (Grisham, 2006). Digital stories possess unique narrative qualities that often center on identity negotiation and the ways culturally and linguistically diverse students make meaning out of their lives.

\footnotetext{
* Yurimi Grigsby, Concordia University Chicago, USA; yurimi.grigsby@cuchicago.edu Carolyn Theard-Griggs, Concordia University Chicago, USA;

carolyn.theardgriggs @ cuchicago.edu

Christopher Lilly, Concordia University Chicago, USA; christopher.lilly@ cuchicago.edu
} 


\section{The increasingly diverse classroom}

Classrooms in the United States have become increasingly diverse and will continue to grow in diversity. Along with numbers of growing racial diversity, linguistic diversity is also growing. One student in every five has a parent who was born in another country (Rehm and Allison, 2006), and twenty percent of all public school students are multilingual (Huerta and Jackson, 2010). According to the National Center of Education Statistics, in 2011-2012, the percentage of English language learners enrolled in public schools was 9.1 percent, or an estimated 4.4 million students (2014). In 2014, the Education Department reported 840,000 immigrant students in the United States, and 4.6 million English learners.

Myriad theories and frameworks have centered on the ways in which students create knowledge and process information, such as differentiated instruction (Tomlinson, 2001), culturally relevant pedagogy (Ladson-Billings, 1995), the multiple intelligences theory (Gardner, 1983), and communities of practice (Lave and Wenger, 1991). These approaches have guided our understanding of how culturally and linguistically diverse students learn, in ways that honor their cultural capital. This is an issue of paramount importance because (1) students of diverse cultural and linguistic backgrounds have historically not been served well by schools and continue to be labeled "at risk" in educational institutions (Garcia and Cuellar, 2006), and (2) the teaching force is largely non-diverse and homogenous, White, middle-class, and female (Hinchey, 2008; Zumwalt and Craig, 2005).

\section{Digital storytelling, second language learners, and the classroom}

English teaching and learning has involved hegemonic discourses that largely strip individual learners of their differences and unique cultural frames of knowledge in favor of adopting an "English-speaking" identity (Shen, 1989). We recognize the value of the voices of diverse learners through considering language acquisition through a sociocultural lens. A benefit of using this lens is that a space is made for individuals who are negotiating their places as English learners, and finding - or recreating - their voices in the process. Digital storytelling as an authentic means of expression promotes learner autonomy, as students reflect on their developing identities and how they deconstruct their experiences in the world.

DST fosters hands-on, active learning in which the storyteller controls the process in every way, giving learners "another tool to find their voices and express themselves in the digital age" (Wawro, 2012, p. 50). Enabled is a type of experiential learning, a learn-by-doing approach. The storyteller must create a story that makes sense, and through this process of meaning-making, higher levels of student engagement are achieved, and opportunities for stronger student 


\section{Acta Technologica Dubnicae \\ volume 5, 2015, issue 1}

learning (Matthews-DeNatale, 2008) are created. "Learners become entranced by the power of their own voices and their own images." (Rance-Roney, 2008, p. 29) We posit digital storytelling as a pedagogical tool for preserving the identity of the learner while also developing the learner's English language skills. Inherent within the process is also room for reflective thought which complements the cognitive and social skills required in completing the story. And because the digital stories can be shared online, the audience can be worldwide, reaching far beyond the classroom in which it was created. "Digital storytelling is an empowering and creative way for kids to tell their stories, and when they are all done, they won't just stick it on their refrigerator - they can share it with the world." (Wawro, 2012, p. 51).

Tsou, Wang, and Tzeng (2006) found that integrating digital storytelling into the language curriculum as a language learning technique improved students' levels of learning in reading, writing, speaking, and listening. The integration of writing skills through DST (rather than teaching writing in isolation) provided evidence that one skill can provide for the development of another (Oxford, 2001).

As literacy/language teachers are rethinking how classroom practices "and the role that new and emerging technologies may play" (Kessler, 2013, p. 231), we recognize the ability of DST to provide more variation than traditional methods in current practice, personalizing the learning experience, and facilitating the involvement of students in the process of learning. DST supports students' learning by encouraging them to organize and express their ideas and knowledge in an individual and meaningful way (Robin, 2005).

Digital stories are an effective strategy for most subject areas and disciplines because of its high applicability. Barrett (2006) found that digital storytelling facilitates the convergence of four student-centered learning strategies: student engagement, reflection for deep learning, project-based learning, and the effective integration of technology into instruction. Schiro (2004) used digital stories to teach students algorithms and problem solving. He argued that digital stories, with other materials like worksheets, not only present mathematical skills that students need to learn but also situate the mathematics in a context that is interesting and relevant. Hung, Hwang, and Huang (2012) found projectbased digital storytelling enhanced their students' science learning motivation, problem-solving competence, and learning achievement.

A common thread we found in studies was the ability to personalize the learning experience in ways that are meaningful to the learner, with the ability to differentiate for the more and less technologically-competent student, or the more and less developed writer. The high "personalizability" factor induces engagement, and facilitates the concept of mirroring, in which a student can see him or herself within the curriculum. The importance of reflecting student experiences in curriculum was noted by Ibrahim, who posited "one invests where one sees oneself mirrored." (Ibrahim, 1999, p. 365). 


\section{Supporting student success through technology}

With digital and online media use becoming ubiquitous in our everyday lives, the way we interact with these forms of communication is having an enormous impact on our literacy and learning. "Our innovation-based global age requires that we retool foundational literacy skills and link them with other competencies - such as critical thinking, collaborative problem solving, and media literacy." (Gee and Levine, 2009, p. 50) Today's learners, asserted Carr (2010), have been changed by the Internet. Digital natives, those who were born or brought up during the age of digital technology (Prensky, 2001, p. 1), demand immediate feedback, interactivity, and shorter reads (Carr, 2010). Technology is changing the way we think, yet while we cannot predict what tools or gadgets will exist tomorrow, we recognize that creating more personalized student experiences is now an expectation because of the participatory culture we are living in (Jenkins, 2013). Digital technologies allow us to create, share, recirculate, express ourselves, and get feedback. Making something and turning it into an artifact we have created is a mode of creative expression (e.g., blogs) that promotes intersubjectivity, or a shared understanding that helps us relate one situation to another (Jenkins, 2013).

Gillen (2014) argued the fields of Linguistics and Composition have largely ignored the study of language in digital contexts, and reading and writing language online, even while digital technologies in everyday life are pervasive from online teenage communities to the professional use of Twitter in journalism, as well as the power of social media to facilitate social uprisings (i.e., Egypt and the Arab Spring). No matter how we plan (or do not) to incorporate it, digital literacy may no longer be optional for the $21^{\text {st }}$ century student and global citizen. Digital media and technological tools allow students to practice these competencies in new and interactive, intriguing and engaging ways.

\section{Strategies for incorporating digital storytelling}

There are numerous ways to incorporate digital storytelling into instruction. Software programs for video creation can be used such as Animoto, iMovie, and Windows Movie Maker 2.6. Narration and music can be included using programs like Audacity. Most programs have a free trial version and some have free or discounted educator versions. For schools without the resources to purchase multiple copies of software programs, teachers can do most of the editing from the storyboards written by the students.

For a two-five minute final project, a story circle can ease learners into starting the process. The steps below can be followed:

1. Story circle

○ story elements: point-of-view, dramatic question, emotional content

- collaboration for collective input 
○ $150-200$ words in length

2. Storyboard

o script

- collection of images/visual data

3. Narration and Music

4. Editing

5. Completed final project

Wawro (2012, p. 51) clarified the process in the following steps:

1. Have the students write out the stories they wish to tell.

2. Record the students telling their stories.

3. Gather their images (their own photos, scanned images, drawings).

4. Arrange the images and audio in the editing software.

5. Go Hollywood - throw in a little movie magic.

6. Export the work to a playable movie file.

Below is another way to incorporate digital storytelling, by Samantha Morra, on Edudema:

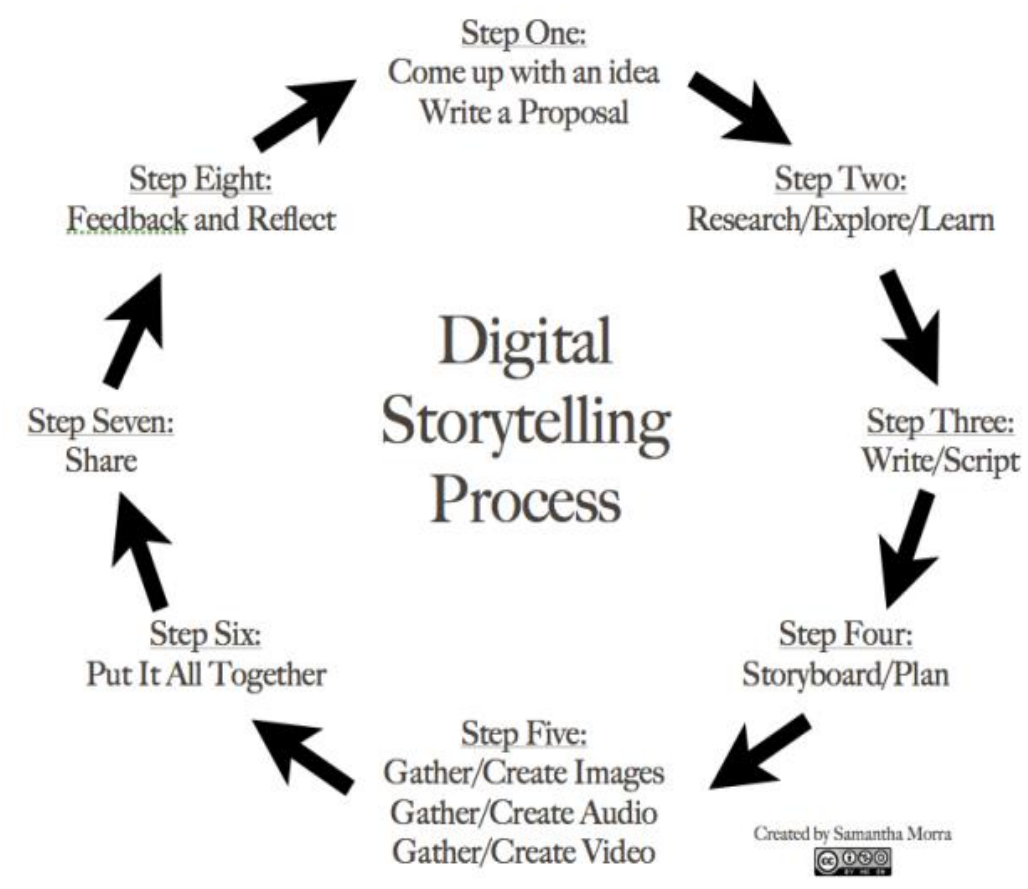

Figure 1. Digital Storytelling Process (Morra, n.d.) 


\section{Assessing and evaluating digital storytelling}

For purposes of assessing digital stories, rubrics can be created and tailored to instruction, either by the teacher's own design or with the assistance of Rubistar, or another online rubric creator. The following links may be helpful for assessment and evaluation and to identify ways to align digital stories to the Common Core State Standards:

http://courseweb.lis.illinois.edu/ jevogel2/lis506/evaluation.html http://www.schrockguide.net/digital-storytelling.html http://www.ucdenver.edu/faculty_staff/faculty/center-for-faculty-development/ Documents/Tutorials/Rubrics/documents/ex_digital_storytelling.pdf

\section{Conclusion}

Teachers are encouraged to look at digital storytelling as a way to garner student engagement while also promoting student learning. Digital storytelling is one approach that allows students to share their experiences and incorporate their own voices in the curriculum. It facilitates student-centered stories that honor their cultural capital, and fosters meaningful expressions that represent what they see in the world, while exploring what feels relevant to them.

\section{References}

BARRETT, H. Researching and evaluating digital storytelling as a deep learning tool. C. CRAWFORD, et al. (Eds.), Proceedings of Society for Information Technology and Teacher Education International Conference 2006. Chesapeake, VA: AACE, pp. 647-654.

CARR, N. The shallows: What the Internet is doing to our brains. New York, NY: W.W. Norton \& Company, 2010.

GARCIA, E., and CUELLAR, D. Who are these culturally and linguistically diverse students? Teachers College Record, 108, 2006, 11, pp 2220-2246.

GARDNER, H. Frames of mind: The theory of multiple intelligences. New York, NY: Basic Books, 1983.

GEE, J., and LEVINE, M. (2009). Welcome to our virtual worlds. Educational Leadership, 66, 2009, 6, pp. 48-52.

GILLEN, J. Digital literacies. New York, NY: Routledge, 2014.

GRISHAM, T. Metaphor, poetry, storytelling and cross-cultural leadership. Management Decision, 44, 2006, 4, pp. 486-503.

HINCHEY, P. Becoming a critical educator. New York, NY: Peter Lang, 2008.

HUERTA, M., and JACKSON, J. Connecting literacy and science to increase achievement for English language learners. Early Childhood Education Journal. [online]. 38, 2010, pp. 205-211. Doi: 10.1007/s10643-010-0402-4.

HUNG, C., HWANG, G., and HUANG, I. A project-based digital storytelling approach for improving students' learning motivation, problem-solving 


\section{Acta Technologica Dubnicae \\ volume 5, 2015, issue 1}

competence and learning achievement. Educational Technology \& Society, 15, 2012, 4, pp. 368-379.

IBRAHIM, A. Becoming black: Rap and hip-hop, race, gender, identity, and the politics of ESL learning. TESOL Quarterly, 33, 1999, 3, pp. 349-369.

JENKINS, H. Textual poachers: Television fans and participatory culture. New York, NY: Routledge, 2013.

KESSLER, G. Preparing tomorrow's second language writing teachers to use technology. [online]. 2013, pp. 213-231. Available from:

$<$ http://lrc.cornell.edu/events/past/2012-2013/papers12/kessler.pdf >

LADSON-BILLINGS, G. But that's just good teaching! The case for culturally relevant pedagogy. Theory Into Practice, 34, 1995, 3, pp. 159-165.

LAVE, J., and WENGER, E. Situated learning: Legitimate peripheral participation. Cambridge, MA: Cambridge University Press, 1991.

MALITA, L., and MARTIN, C. Digital storytelling as web passport to success in the 21st century. Procedia - Social and Behavioral Sciences, 2, 2010, 2, pp. 3060-3064.

MATTHEWS-DENATALE, G. Digital storytelling: Tips and resources. Boston, MA: Simmons College, 2008.

MAWWELL, L. U.S. school enrollment hits majority-minority milestone. [online]. EdWeek.org, August, 2014. Available from:

$<$ http://www.edweek.org/ew/articles/2014/08/20/01demographics.h34.html>

MEADOWS, D. Digital storytelling: Research-based practice in new media. Visual Communication, 2, 2003, 2, pp. 189-93.

MEEKS, M. On being literate. Portsmouth, NH: Heinemann Educational Books, Inc., 1991.

National Center for Education Statistics. The condition of education: English language learners. [online]. April, 2014. Available from:

$<\mathrm{http}: / /$ nces.ed.gov/programs/coe/indicator_cge.asp $>$

OXFORD, R. Integrated skills in the ESL/EFL classroom. 2001. Available from ERIC database. (ED456670).

PEDERSEN, E. Storytelling and the art of teaching. English Teaching Forum, 33, 1995, 1, pp. 2-5.

PRENSKY, M. Digital natives, digital immigrants. On the Horizon. [online]. NCB University Press, 9, 2001, 5. Available from: $<$ http://www.marcprensky.com/writing/Prensky\%20-\%20Digital\%20Natives, $\%$ 20Digital\%20Immigrants\%20-\%20Part1.pdf $>$

RANCE-RONEY, J. Digital storytelling for language and culture learning. Essential Teacher, 5, 2008, 1, pp. 29-31.

REHM, M., and ALLISON, B. Positionality in teaching culturally diverse students: Implications for family and consumer sciences teacher education programs. Family and Consumer Sciences Research Journal, 34, 2006, pp. 260275. 


\section{Acta Technologica Dubnicae \\ volume 5, 2015, issue 1}

SCHANK, R. Tell me a story: A new look at real and artificial memory. New York, NY: Charles Scribner, 1990.

SHEN, F. The classroom and the wider culture: Identity as a key to learning English composition. College Composition and Communication, 40, 1989, 4, pp. 459-466.

SCHIRO, M. Oral storytelling and teaching mathematics. Thousand Oaks, CA: SAGE Publications, 2004.

ROBIN, B. The educational uses of digital storytelling. Available from: $<\mathrm{http}: / /$ digitalliteracyintheclassroom.pbworks.com/f/Educ-Uses-DS.pdf $>$

TOMLINSON, C. How to differentiate instruction in mixed-ability classrooms. Virginia: ASCD, 2001.

TSOU, W., WANG, W., and TZENG, Y. Applying a multimedia storytelling website in foreign language learning. Computers \& Education, 47, 2006, pp. $17-$ 28.

VINOGRADOVA, P. Digital stories in heritage language education: Empowering heritage language learners through a pedagogy of multiliteracies. WILEY, T., PEYTON, J., CHRISTIAN, D., MOORE, S., and LIU, N. (eds.). Handbook of heritage, community, and Native American languages in the United States: Research, policy, and educational practice. New York, NY: Routledge, pp. 314-323.

WAWRO, L. Digital storytelling: More than the sum of its parts. Children \& Libraries: The Journal for the Association for Library Service to Children, 10, 2012, 1, pp. 50-52.

YANG, Y-T., and WU, W-C. Digital storytelling for enhancing student academic achievement, critical thinking, and learning motivation: A year-long experimental study. Computers \& Education, 59, 2012, pp. 339-352.

ZUMWALT, K., and CRAIG, E. Teachers' characteristics: Research on the demographic profile. COCHRAN-SMITH, M. and ZEICHNER, K. Studying Teacher Education: The Report of the AERA Panel on Research and Teacher Education. Mahwah, NJ: Lawrence Erlbaum Associates, 2005, pp. 111-156. 